\title{
Submarine Mass Failures as tsunami sources - their climate control
}

\author{
By D.R. Tappin
}

\author{
British Geological Survey, Nottingham, NG 12 5G G, UK
}

Recent research on Submarine M ass Failures (SM Fs) shows that they are a source of hazardous tsunamis, with the tsunami magnitude mainly dependent on water depth of failure, SM F volume and failure mechanism; cohesive slump or fragmental landslide. A major control on the mechanism of SM F is the sediment type, together with its postdepositional alteration. The type of sediment, fine- or coarse-grained, its rate of deposition together with post-depositional processes may all be influenced by climate. Post-depositional processes, termed sediment 'preconditioning' is known to promote instability and failure. Climate may also control the triggering of SM Fs, for example through earthquake loading or cyclic loading from storm waves or tides. Instantaneous triggering by other mechanisms such as fluid overpressuring and hydrate instability is controversial, but is here considered unlikely. However, these mechanisms are known to promote sediment instability. SM Fs occur in numerous environments, including the open continental shelf, submarine canyon/fan systems, fjords, active river deltas and convergent margins. In all these environments there is a latitudinal variation in the scale of SM F. The database is limited, but the greatest climate influence appears to be in high latitudes where glacial/interglacial cyclicity has considerable control on sedimentation, preconditioning and triggering. Consideration of the different types of SMF in the context of their climate controls provides additional insight into their potential hazard in sourcing tsunamis. For example, in the A tlantic, where SM Fs are common, the tsunami hazard under present day climate may not be as great as their common occurrence suggests.

Keywords Tsunami $\bullet$ submarine mass failure $\bullet$ hazard $\bullet$ climate

\section{Introduction}

Tsunamis, especially destructive ones, are mainly $(\sim 70-80 \%)$ caused by earthquakes. However, they can also be sourced by failure of sediment and rock both on land and at the seabed. M ost of these sediment/rock failures are in submarine sediments or from volcanic lateral collapse. Historical records of destructive tsunamis caused by lateral collapse include $18^{\text {th }}$ century examples from Japan, such as Oshima-O shima in 1741 (Satake and K ato, 2001; Satake, 2007) and Unzen in 1792 (Siebert et al., 1987) as well as the 1888 AD collapse of Ritter Island in Papua N ew Guinea (J ohnson, 1987; W ard and Day, 2003). Such historical ocean-entering landslides are recognized from eyewitness accounts. In contrast, prehistorical lateral collapses, such as those in Hawaii and the Canary Islands, are identified from geological evidence (e.g. M oore et 
al., 1994; U rgeles et al., 1997). This difference in identification is significant in terms of hazard recognition. Submarine seabed failures, termed here Submarine Mass Failures (SMFs), are less easily recognised than those onland, and there are few historical accounts of these events. Thus SMFs may have been underestimated as a tsunami source. In fact, until recently, they were discounted as a cause of destructive tsunamis (e.g. Jiang and LeB lond, 1994; LeBlond and Jones, 1995). T sunamis such as the Grand Banks in 1929 (e.g. Heezen et al., 1954; Piper and Asku, 1987) and those associated with the Good Friday 1964 earthquake in A laska, at Seward and Valdez (e.g. Lee et al., 2003) might have flagged the hazard but they did not. It was not until 1998, when a submarine slump caused the devastating tsunami at Sissano Lagoon in Papua New Guinea, in which 2,200 people died, that the threat from submarine landslides was fully realized (Tappin et al., 1999; Tappin et al., 2001; Tappin et al., 2008).

Since 1998 there have been major advances in understanding SM Fs as sources of tsunamis. Applying new mapping methodologies, such as multibeam bathymetry, the numerous architectures of SM Fs have been identified. Additionally, there has been an improved understanding of the mechanisms of SMF, including their formation and triggering. Based on the new knowledge, advanced parametric mathematical models of SMF have been developed that form the basis of more realistic tsunami wave propagation and runup (Tappin et al., 2008). Thus SM Fs and their potential to generate hazardous tsunamis are now much better understood. An aspect of this improved understanding is the influence of climate on both their formation and triggering. It is, therefore, the objective of this paper to present an overview of the tsunami hazard from SM Fs in the context of their climate control(s). Specifically to, i) consider the temporal evidence on how climate change may relate to $S M F$, ii) how climate change may influence the stability of submarine sediments leading to mass failure, iii) whether climate can control the triggering of SM Fs and iv) how climate, and associated sea level change may influence the preservation potential of tsunami sediments derived from SM Fs and thereby our potential to recognise in the geological record SM Fs as tsunami sources. The focus of the paper is on non-volcanic SM Fs, although it is recognised that volcanic mass failure may also pose a significant tsunami hazard.

\section{Submarine $M$ ass F ailures}

SM Fs range from cohesive slumps to translational landslides (Hampton et al., 1996). Study of SM Fs has advanced our understanding of, i) their role in the transport of sediment from the land to the ocean, ii) their potential as deep-water hydrocarbon reservoirs and iii) their hazard to seabed infrastructure, particularly in relation to the hydrocarbon industry. The recent realisation that SM Fs may cause hazardous, if not devastating, tsunamis has also led to new research in this context. Controls on SM F are many and varied and include their sediment properties resulting from initial deposition and post-depositional alteration, termed 'preconditioning', together with 'triggers' that are instantaneous events causing sediment failure. Deposition and postdepositional alterations are the result of uplift and erosion and basin subsidence. 
Tectonics undoubtedly influences sedimentation by creating depositional, 'accommodation' space with uplift of sediment source areas leading to erosion and deposition. There has been considerable debate about how the environment of sediment deposition may contribute to sediment failure by 'preconditioning' sediment physical properties (e.g. Biscontin et al., 2004; M asson et al., 2009). Earthquakes are recognised as the main SM F trigger (e.g. B ugge, 1983; Laberg et al., 2000), but other mechanisms include salt movement, storm wave loading and low tides (Prior et al., 1982a; Prior et al., 1982b; Twichell et al., 2009). Triggers, such as increases in sediment pore pressures and hydrate destabilisation, are more controversial (see discussion in Dugan and Stigall, 2009; Grozic, 2009).

A nother first order control on sedimentation of SMFs is global climate change. During recent Earth history, over the past hundreds of thousands of years, global climate has fluctuated with remarkable cyclicity. A major result of these fluctuations is the variation in the expansion and contraction of continental ice sheets that have resulted in eustatic sea level changes of up to $120 \mathrm{~m}$. A consequence of these glacial/interglacial cycles is a variation in the rate of sediment delivery to the ocean. The combined effects of climate and sea level change result in changes in location of SMFs along the ocean margins. For example, at high latitudes the large volumes of sediment delivered to the ocean margins during glacial periods are destabilised by earthquakes that result from glacioisostatic uplift as the ice sheets melt and contract (Bryn et al., 2005). A t mid and lower latitudes the glacial influence is less evident and the database less substantial, but here also there is evidence of a climate control on SM F (e.g. Gee et al., 1999; Henrich et al., 2009).

\section{$3 \quad$ Landslide Territories}

SM Fs take place in many different environments and Hampton et al. (1996) introduced the term "landslide territory" for areas where they are more common than elsewhere (Figure 1). These environments include the open continental shelf, submarine canyon/fan systems, fjords, active river deltas and volcanic islands. In addition, Lee (2005) identified convergent margins as an environment where submarine landslides also take place. Recent research in the South Pacific on reef-front environments suggest that these too may be prove to be a location where SM F can cause hazardous tsunamis, as in the Suva, Fiji event of 1953 (Rahiman et al., 2007).

The locations of SMFs are identified by unique combinations of sedimentology and physiography, with common factors including thick sedimentary deposits, sloping seafloor and high environmental stresses. Several dominant controls on slope stability are recognised that include, i) the rate, volume and type of sediment delivery to the continental margins; ii) sediment thickness, iii) changes in seafloor conditions, which can influence hydrate stability and the possible generation of free gas, iv) variations in seismicity and v) changes in groundwater flow. With regard to tsunami generation, there is a recognisable close and genetic relationship to most landslide territories. On open continental slopes and canyons, fjords and convergent margins, there is evidence that SM Fs can result in hazardous, if not, devastating tsunamis. Examples include the 
Grand B anks event of 1929, A laska in 1964, PNG in 1998 and Storegga at 8,200 years $B P$. However, on active river deltas, there is no evidence of tsunamis sourced from SM Fs. For example, submarine landslides are common on the M ississippi Delta (Prior and Coleman, 1982) yet no associated tsunami has yet been recognised.

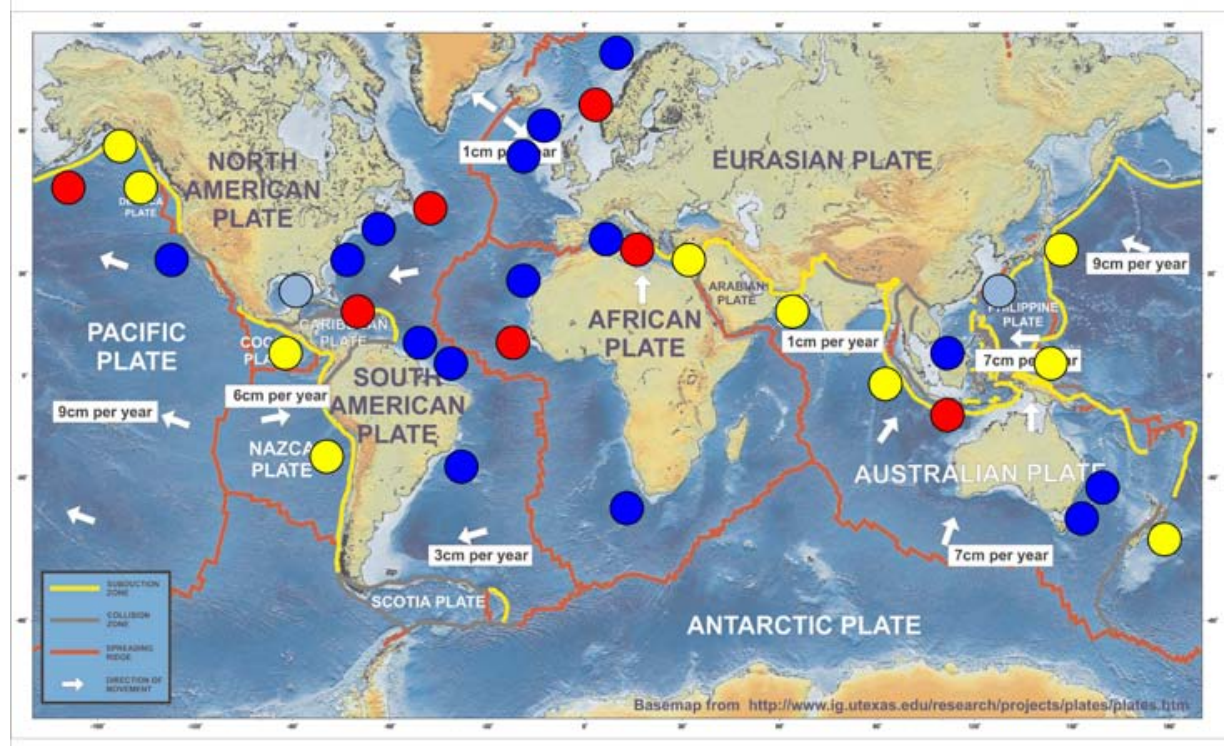

Figure 1. Global distribution of mapped SMFs. Blue dots - SMFs on continental shelves and fan systems - no identified tsunami. Y ellow dots - SM Fs located along convergent margins, no identified tsunami. Red dots - Locations of SM F sourced tsunamis, or where there may be a SM F contribution. Grey-blue dots - Active river systems - no tsunami identified.

\subsection{Open Continental Slope and Rise}

A long continental margins major sediment transfer takes place from land to sea, with slope canyons resulting from erosion and fan/delta systems from deposition. During changes in sea level, sediment in these regions has the potential to become unstable, in the process triggering tsunami. The North Atlantic is one of the best studied regions (M cA doo et al., 2000; Hühnerbach et al., 2004; Lee, 2009), and here there is an extensive database of SMFs that includes their depositional character, age, and proposed triggering mechanisms. Off of N orway, the discovery of the second largest gas field in Europe, located beneath the largest submarine landslide in the North A tlantic, resulted in one of the most intensive investigations into offshore slope stability ever undertaken (B ryn et al., 2005; Solheim et al., 2005).

SM Fs at all scales are common along the A tlantic continental margins. M echanisms of sediment mass movement include, debris flows, landslides, turbidity flows and slumps. 
Generally, they are more abundant in the western North A tlantic (off Canada and the USA) than in the eastern N orth A tlantic (off Europe and A frica). In the west, SM Fs are smaller than those in the east. On both sides of the A tlantic, most SM Fs originate in water depths between 1,000 and $1,300 \mathrm{~m}$. Three climatic regions may be identified where SM Fs take place: a glaciated margin north of $56^{\circ} \mathrm{N}$ (southern tip of Norway), a "glacially-influenced" margin from $26^{\circ} \mathrm{N}$ to $56^{\circ} \mathrm{N}$, and a non-glaciated margin south of $26^{\circ} \mathrm{N}$ (W eaver et al., 2000). However, these boundaries reflect present day climate and have fluctuated as this has changed. During glacial maximums, for example, the limit of glacial margins is located at least 10 degrees farther south than at present.

\subsubsection{Glaciated margins}

In the eastern A tlantic, four major SM Fs border the Norwegian margin; A ndøya, Trænadjupet, Finneidfjord, and Storegga. Farther south, off B ritain and Ireland, large SMFs include Peach and Rockall located off of Scotland. The Storegga slide is the largest SM F in the A tlantic with a volume of $3,500 \mathrm{~km}^{3}$. It generated a tsunami that struck the west coast of Norway with runups of up to $20 \mathrm{~m}$ and propagated outward striking Scotland and the Faeroes with runups of 5 to $10 \mathrm{~m}$ (B ondevik et al., 2005).

In high latitude, glaciated, regions there is a dynamic evolution of SM Fs that is related to sea level fluctuations associated with ice sheet advance and retreat. Sedimentation rates are highest during glacial periods, with 36 to $65 \mathrm{~m} / \mathrm{ky}$ for the Trænadjupet and Storegga SM Fs respectively (Laberg et al., 2003; Hjelstuen et al., 2005). During interglacials sedimentation rates are much reduced, with less than one $\mathrm{m} / \mathrm{ky}$ being common. These rates reflect the large volumes of sediment produced from ice sheet scouring during glacial episodes, with less sediment delivered during interglacials when ice sheets are smaller and more distant and sedimentation is mainly from slope parallel contourites. The result of these changing sedimentation regimes is complex sediment preconditioning that includes the development of high pore pressures in the fine-grained glacial sediment that results in destabilisation through earthquake loading.

The failure of Storegga is probably representative of similar SMFs along the Norwegian margin (Bryn et al., 2005). Failure took place at the end of the last glaciation or soon after deglaciation. It was translational and took place along weak layers formed in marine clays subject to strain softening. Prior to failure, destabilization was the result of rapid loading from glacial deposits, causing the generation of excess pore pressure and reduction of effective shear strength in the underlying clays. Initiation of failure was at water depths of 1,500 to $2,000 \mathrm{~m}$ with retrogressive failure propagating upwards from the base. Climatic processes led to a preconditioning of the sediment mass. During glacial periods, when sea level was lowered, the ice sheet advanced to the shelf break depositing large volumes of coarsegrained sediment on the slope. During interglacials, higher sea levels resulted in slopeparallel contour currents from which finer-grained sediment was deposited. These finegrained clays formed weak layers al ong which failure of the sediment mass took place. Failure was triggered by earthquakes caused by isostatic uplift as the ice sheets melted. Although hydrate destabilization may contribute locally, this is not regarded as a primary driver of mass failure. 
In the western A tlantic, off of Canada, 24 SM F s have been mapped (Piper and M CCall, 2003). The SM Fs vary in morphology from slides to retrogressive slumps. They are located in pro-delta settings, on the continental rise and in steep-sided canyons. The oldest is $125 \mathrm{ky}$, although most are younger than $50 \mathrm{ky}$. 14 failures occurred during the last glacial period. Only two are post-glacial, the best known of which is the Grand B anks event of 1929, when 41 people lost their lives in the resultant tsunami. The 1929 SMF was a debris flow and turbidite released from the Canadian shelf by an earthquake. It is relatively thin (20 m average) and probably retrogressive (M osher and Piper, 2007). Off of Nova Scotia, there are five main episodes of mass wasting over the past $17 \mathrm{ky}$, at 5-8 ky, $12.7 \mathrm{ky}, 13.8 \mathrm{ky}, 17.9 \mathrm{ky}$ and $14 \mathrm{ky}$. Thus SM F took place mainly during glaciation, with a glacial/interglacial ratio of failure of 3 or 4 to 1 . Their broad geographic distribution suggests an earthquake trigger for all these events (J enner et al., 2007), with earthquakes the result of post-glacial crustal rebound. This readjustment is still ongoing (e.g. Peltier, 2002).

\subsubsection{Glacially influenced margins}

There are few large SMFs off the European margins where narrow shelves and common submarine canyons mainly funnel turbidity currents to the abyssal plain. Off the US margin, however, 55 SM F s have been identified (C haytor et al., 2007; T wichell et al., 2009). Two types of SMFs are recognised: those originating in submarine canyons and those from the open continental slope and rise. They cover $33 \%$ of the continental slope and rise of the glacially influenced New England margin, $16 \%$ of the sea floor offshore of the fluvially-dominated M iddle A tlantic margin, and $13 \%$ of the sea floor south of Cape Hatteras. Their distribution is in part controlled by the Quaternary evolution of the margin, resulting from climate controlled eustatic sea level change. The headwall scarps of open-slope SMFs are mainly located on the lower slope and upper rise; those of the canyon sourced SM Fs lie mostly on the upper slope. SMFs are generally thin (mostly 20-40 m thick) and comprised primarily of Quaternary sediment. V olumes of the open-slope SM Fs are generally larger (up to 392 $\mathrm{km}^{3}$ ) than the canyon-sourced ones (up to $10 \mathrm{~km}^{3}$ ). Largest SM Fs along the southern $\mathrm{N}$ ew England margin are located seaward of shelf-edge deltas laid down during the lowered sea levels of the last glaciation. South of Cape Hatteras, SM Fs are located adjacent to salt domes that breach the sea floor. The wide spatial distribution of landslides indicates a variety of triggers, although earthquakes are recognised as the most common, probably generated by glacioisostatic rebound of the glaciated margin, or by salt movement. Other triggering processes, such as fluid overpressuring, may have contributed to failure by pre-conditioning. The large-volume open-slope landslides have the greatest potential to generate hazardous tsunamis. Few of the SM Fs have been dated, but most are considered to have formed during the last glaciation and early Holocene (E mbley and J acobi, 1986).

The Cape Fear Slide is the largest SM F on the US margin, with a volume of $200 \mathrm{~km}^{3}$ (Lee 2009). It is dated at between 8 and $25 \mathrm{ky}$, forming at the transition between the end of the last glaciation and present interglacial. Salt movement, driven by sediment loading, is considered the most likely triggering mechanism, with salt diapirism causing oversteepening of the seabed slope followed by failure. The headwall lies 
along a major normal fault (Cashman and Popenoe, 1985; Hornbach et al., 2007). The Curritick SM F has a volume of $165 \mathrm{~km}^{3}$ and formed on a shelf-edge delta (Prior, David B. et al., 1986). It formed between 24 and $50 \mathrm{ky}$, during glaciation (Locat et al., 2009). Very high pore pressures and/or a strong earthquake are considered the most likely triggering mechanisms. The high pore pressures are attributed to fluid seepage from coastal aquifers, sediment loading from delta construction, local sediment loading, gas hydrates and/or earthquakes. Modelling of the two slides as tsunami sources indicates that they both have the potential to be a hazard today (Hornbach et al., 2007; Geist et al., 2009). However, they formed at lower sea levels, thus making their hazard at time of deposition much greater. To date, no evidence has been found to indicate that a tsunami was generated by these SMFs (see section 4 for further discussion).

\subsubsection{Non-glaciated margins}

Off of N orth A frica there are a number of SM F complexes, although little evidence has been found (or in fact looked for) that indicates associated tsunamis. Off the M oroccan margin a complex of turbidites extends over $1700 \mathrm{~km}$ to seaward (W eaver et al., 2000; Wynn et al., 2002). The turbidites are up to 200-250 ky. The largest are the Bed 5 event off M orocco and, farther south off of the W estern Sahara, the Saharan debris flow. B oth are dated at 50-60 ky (Gee et al., 1999; Wynn et al., 2002). Thus both were triggered when global climate was changing between glacial and interglacial conditions. B oth are associated with changes in eustatic sea level, when this was either rising or falling rapidly. Farther south, off of M auritania, turbidite complexes are also clearly climate controlled (Henrich et al., 2009). There is a high frequency of failure during deglaciation, when sea level was rising, through remobilisation of large-scale aeolian dune fields that had expanded to the shelf edge during glacial sea level lows. Pervasive, and widespread, fluid escape structures suggest high fluid pore pressures that may have initiated failure (A ntobreh and $\mathrm{K}$ rastel, 2006). A ntobreh and $\mathrm{K}$ rastel (2006) also propose that slide formation was pre-conditioned by uninterrupted deposition of organic-rich sediment, the result of upwelling, in an open slope environment. The result was a rapid accumulation of poorly consolidated bedded sediment (turbidites) intercalated with thin weak layers of organic rich sediment. Turbidite activity is also frequent during glacial periods; an increase that is attributed to rapid sea level rise during Heinrich events. Henrich et al. (2008) speculate that the presence in one core of a turbidite overlying a debris flow may indicate an associated tsunami. Triggers in this area are undefined, but North A frica is an earthquake prone area, as recorded in the massively destructive event that struck A gadir in 1960, thus earthquake triggers are a likely source. The synchronicity of turbidite events between the Dakar and Timiris canyons also suggests an earthquake trigger.

SM F s have been mapped in the south A tlantic, although to date there is no evidence of any associated tsunamis, although again these have not been looked for. Off the A mazon Delta, there are large-volume (up to $2,500 \mathrm{~km}^{3}$ ), catastrophic failures of the continental slope. These failures are sourced from rapidly deposited, underconsolidated sediment laid down on upper-fan levees (Piper et al., 1997; M aslin et al., 1998). The dating is poor, but suggests a late glacial to early Holocene age. If correct, 
then the failures may correlate with climate-induced changes in sea level. Failure is attributed to either, i) rapid sea level fall, that resulted in destabilisation of gas hydrate, and/or ii) deglaciation in the Andes leading to the large-scale flushing of Amazon River sediment onto the continental slope; resulting in excessive loading of fan sediment laid down previously during glacially-induced sea level lows. Y oungest failures are 14-17 ky (M aslin et al., 1998), with older events at $35 \mathrm{ky}$ and 42-45 ky. $\mathrm{H}$ ydrate disassociation is mainly associated with the younger events.

Off $\mathrm{B}$ razil, the Rebelde complex is believed to have been triggered by either an earthquake or high fluid pore pressure. A gain the SM F is poorly dated (A shabranner et al., 2009). Off of southern Africa, the Agulhas Slump has a proposed volume of $20,000 \mathrm{~km}^{3}$, although this figure is based on single-beam, bathymetry data (Dingle, 1977).

\subsubsection{Other areas}

Outside of the A tlantic, there are numerous SM Fs although there is little evidence of associated tsunamis with the notable exception of the Nice event of 1979 in which 12 people died (Dan et al., 2007). There has been little research on the relationship between SM F and climate. In the Mediterranean, probably the largest SM F is the 'BIG'95 debris flow off of Spain, with an area of 2,000 $\mathrm{m}^{2}$ and dated at $11.4 \mathrm{ky}$ (Lastras et al., 2004). Proposed triggering mechanisms include seismicity and oversteepening of the slope due to a volcanic structure underlying the main headwall.

SM Fs have been identified off $F$ rance and in the eastern M editerranean off of Egypt and Israel. Two major SM Fs lie off California. The Goleta Slide, in the Santa B arbara Channel, is a compound failure with a total volume of $1.75 \mathrm{~km}^{3}$. It is formed of three main lobes with both surfical slump blocks and mud flows. It is interpreted as Holocene in age (Fisher et al., 2005; Greene et al., 2005). Earthquakes are a likely trigger because historically, earthquakes of magnitudes $\cdot 5$ occur about every $\sim 20$ years. M odelling of one lobe of the Goleta Slide as a tsunami source produces a local runup of $\sim 10 \mathrm{~m}$ (Greene et al., 2005). Records show that tsunamis struck the area in the nineteenth century, but these appear to be sourced from earthquakes rather than SM F s. The Pal os V erdes debris avalanche is located in a submarine canyon offshore of Long B each (B ohannon and Gardner, 2004). It is the largest late Q uaternary SM F, with a volume of $0.34 \mathrm{~km}^{3}$, in the inner California Borderland basins. It is dated at 7.5 ky (Normark et al., 2004). M odelling indicates that it was large enough to generate a significant tsunami that would inundate the adjacent coastline (Locat et al., 2004). However, as of yet, there is no evidence that such a tsunami struck the coast.

\subsection{F jords}

SMFs are common in fjords (Syvitski et al., 1986; Hampton et al., 1996) with numerous records of associated tsunamis. In these glacial environments rapid sedimentation results in deposits that are susceptible to failure. Streams that drain glaciers, transport and deposit sediment formed of low plasticity rock flour that is vulnerable to earthquake loading; rapid sedimentation can lead to underconsolidation. Organic matter deposited from rivers may decay to produce methane gas that may lead to 
elevated pore pressure and further reduce sediment strength. Thus there is a strong climate control both on the location of the fjords and the volume of contributed sediment.

Fjord-head deltas can fail under cyclic loading (e.g. Prior, D. B. et al., 1986). For example, at Kitimat Fjord in B ritish Columbia in 1975, a landslide was triggered by a low tide, creating a tsunami up to $8.2 \mathrm{~m}$ in height (Prior et al., 1982a; Lee, 1989). Although there was significant damage, no lives were lost. W eak delta sediments can also fail through earthquake loading, as happened during the great A laska earthquake of 1964. The resulting tsunamis were enormously destructive, with loss of lives and damage to infrastructure (Plafker et al., 1969; Lee, 1989; Hampton et al., 1993). At Seward a one $\mathrm{km}$ section of the waterfront collapsed as a result of submarine failure, creating a $10 \mathrm{~m}$ high tsunami (Lemke, 1967). The destruction was compounded by a subsequent earthquake-generated tsunami, al so $10 \mathrm{~m}$ high, arriving 30 minutes later. M ost of the 13 people who died at Seward were killed by the tsunami. At V aldez, an initial landslide volume of $0.4 \mathrm{~km}^{3}$ increased to $1 \mathrm{~km}^{3}$ as it incorporated sediment from the seabed (Coulter and Migliaccio, 1966). The resulting tsunami attained heights up to $52 \mathrm{~m}$, and resulted in the loss of 32 lives.

\subsection{Convergent Margins}

Convergent margins, like passive margin open continental slopes and rises, are important regions of sediment flux between the land and the sea. Their characterization into those margins where the sediment flux is significant (sediment rich) and those where it is not (sediment starved) has implications for SM F, although the relationships are complex (Tappin, 2009). It is not always those margins where sediment flux is large that produce the most hazardous tsunami. For example, the PNG event at Sissano Lagoon in 1998 took place along the New Guinea Trench which is sediment starved (Tappin et al., 2001). Conversely, along the Sunda margin, where there is a much larger accretionary prism than in New Guinea, SM Fs are small-scale and less of a hazard in sourcing destructive events (T appin et al., 2007).

SMFs have been mapped along many convergent margins (M CA doo et al., 2004). Their size varies from 'super-scale' in Cascadia (Goldfinger et al., 2000) to 'small' along the Sunda margin in the Indian Ocean (Tappin et al., 2007). Off J apan, there are large SM Fs on the upper parts of the Nankai accretionary prism (Kawamura et al., 2009) but the highly eroded lower slopes show little evidence of large, well-preserved events (M CA doo et al. 2004). A long the Makran and Kodiak accretionary margins there is evidence of mass wasting on the upper slopes, with the lower slopes lacking large SM Fs. By contrast, al ong the sediment-starved Sanriku (J apan), Nicaragua, and A leutian margins there are large SM Fs. In the Gulf of A laska, there are a number of large SM Fs located on the shelf and the continental slope. B oth slumps and debris flows are present and their formation is attributed to glacial processes (Schwab and Lee, 1988; Dobson et al., 1998). During climatic cooling there is increased sediment delivery to the slope through expansion of tidewater glaciers, with resultant formation 
of point-sourced fans. During interglacials, as sea levels rise, sediment is delivered onto the shelf. Triggering is either by earthquake or storm wave loading.

Since the Sissano, PNG tsunami of 1998, research into convergent margin tsunamis from SM Fs has increased significantly. Some studies are based on newly acquired multibeam data, e.g., Puerto Rico, 1918 (López-V enegas et al., 2008). Other studies have re-evaluated anomalous tsunamis with runups that, to some degree, are too large in relation to their proposed earthquake source, e.g. M essina, 1908 and A laska, 1946 (Fryer et al., 2004; Billi et al., 2008). Other events, where there are inconsistencies between earthquake magnitude/location and tsunami runup, include the Makran, Indian Ocean event of 1945 (Rajendran et al., 2008), Sanriku in 1896 (Tanioka and Seno, 2001), Flores Island in 1982 (Imamura et al., 1995) and Java, 2006 (Fritz et al., 2007).

\section{SM F, T sunamis and C limate control}

In most, if not all, of the landslide environments described there is evidence of strong climate control on SMF; on initial deposition, post-depositional preconditioning of sediment, as well as on triggering. The type of sediment laid down, fine- or coarsegrained, the rate of deposition and post-depositional alteration are all influenced to greater or lesser degree by climate. The location of SM Fs is also climate controlled through changes in eustatic sea level. $Y$ et there are obvious variations and differences in how climate controls SMF in the different landslide territories. There are both temporal variations over hundreds of thousands of years, associated with global, astronomically-forced, climate change together with geographic variations that are related to present-day climate and the various tectonic environments in which the landslide territories occur. Finally, in the context of tsunamis, there is the evidence on which the relationship between SMF and tsunamis is based, whether this is representative and, if not, why. These interrelations between climate, SM F and tsunami generation are, therefore, complex in temporal, geographic and tectonic frameworks.

\subsection{Temporal relationships between climate change and SM F $\mathbf{s}$}

Evidence from the most intensively studied region of the A tlantic, reveals a strong climate control on the mass-wasting systems of the region that is related to the cyclical changes over the past hundreds of thousands of years that relate to glacial and interglacial periods. In the high-latitude, glacially-dominated, continental margins off Norway, the thick sedimentary deposits laid down during glacial periods and interbedded, thinner finer-grained sediments laid down during interglacials, are prone to failure, triggered from increased seismicity (caused by isostatic readjustment) during deglaciation. Farther south along the glacially-influenced margins of the USA, there is also climate control on sedimentation. During the cyclical glacial/interglacial periods changing eustatic sea level controls the location of sediment deposition, as well as the rates of sedimentation. Compared to glaciated margins, sediment delivery 
is much reduced, thus SM F volumes are smaller by an order of magnitude. Largest SM F $\mathrm{s}$ are on the margin of shelf-edge deltas, where rapid sedimentation during glacial lowered sea levels results in a potential for subsequent catastrophic failure as sea level rises.

A long the low latitude margins off W est A frica, although the database is more limited, climate control is reflected in the turbidite mass failures that correlate with climate induced sea level change. Off $M$ auritania, turbidites are the sourced from the desert sands that advance to the shelf edge during sea level lows. Smaller SM F relate to climate controlled rates of sedimentation, in association with different types of sediment deposited between glacial and interglacials. Organic rich fine-grained sediments resulting from upwelling during sea level highs form weak layers along which failure takes place. Along convergent margins, although the evidence base is again limited, variation in sediment supply in high latitudes, such as along the A laska margin, is related to glacial/post-glacial sediment variation (e.g. Schwab and Lee, 1988; Dobson et al., 1998).

A major constraint on identifying temporal control is undoubtedly the relatively poor accuracy of landslide dating and the limited number of reliable ages. Thus climate induced controls, such as on relatively brief periods of sea level fall, remains uncertain. Notwithstanding, the dates available indicate that over the last 20,000 years, there is a relatively even distribution of large landslides in the period between the last glacial maximum until about 4,000 years ago. These failures are in sediments deposited during lowered sea levels, interbedded with weak layers that form during interglacials, and prone to destabilisation during warming and deglaciation. Evidence of two relatively recent tsunamis from SM F (Storegga, 8,200 BP and Grand Banks in 1929) in these glacially dominated, northern regions suggests that the present-day hazard here may be high. However, where triggering of failure is mainly through glacioisostatic rebound, the decline in seismicity may well result in the hazard today not being as great as perceived, (as proposed by B ryn et al. 2005).

\subsection{Does climate influence preconditioning of submarine sediment sequences to mass failure?}

Climate preconditioning of sediment failure is recognised in many regions of the A tlantic. Off of N orway, the change in sedimentation between glacial and interglacials results in loading of fine-grained sediments thereby creating high pore pressures, and resulting in sediment susceptible to failure from earthquake loading. In fjords, rapid deposition of organic rich sediment on fjord head deltas also leads to high pore pressures and gas rich sediment, resulting in sediment that is sensitive to cyclic loading from storms and earthquake shock. Recent studies from the Gulf of M exico (Dugan and Stigall, 2009) and Storegga (K valstad et al., 2005) show that high pore pressures resulting from rapid sedimentation, can precondition SMF, but an external instantaneous trigger, such as an glacioisostatic earthquake, or salt movement is still required. Thus the sediment preconditioning is climate related, although triggering may be mainly from another source. 


\subsection{Climate change as a trigger mechanism for SM F s}

There has been much discussion about the instantaneous triggers of SM F. Earthquakes are undoubtedly the most common triggers. Others include storms, tides and salt movement. More controversial is triggering resulting from instantaneous hydrate destabilisation and pore fluid overpressuring. There is much circumstantial evidence on the association between hydrates and SM F, for example, the relationship between the headwall scarps of SM F with the intersection of the hydrate stability zone at the seabed. Hydrate dissociation was considered as a trigger of the Storegga slide, but this has been discounted as a major factor (Bryn et al. 2005). Suggestions that rapid methane increase during past interglacials is from SM $\mathrm{F}$ has now been disproved from isotopic ice core evidence (Sowers, 2006).

Thus, although hydrate disassociation and sediment fluid overpressures may precondition sediment for subsequent failure, under present climates an external force, such as from earthquake loading, is still required to actually initiate failure (B ryn et al., 2005; Dugan and Stigall, 2009). Elevated pore pressure is undoubtedly a significant factor in reducing sediment shear strength, but geotechnical analyses have failed to confirm that these can cause instantaneous failure. M ost SM Fs dated by Lee (2009) from the last 20,000 years, were emplaced during stable or rising sea level, a period when hydrate disassociation would be least expected. In the future, however, if predictions of rapid global warming are correct, then hydrate stability in shallow ocean waters may be affected. In polar regions, where present models suggest warming will be most rapid this may result in an increased potential for hydrate destabilisation (B etts and McGuire, 2010; M aslin et al., 2010). In high latitudes, SM F triggering by earthquakes during late- to post-glacial periods is well established, with the earthquakes resulting from glacioisostatic readjustment as ice sheets melt and retreat. In both Canada and northern Europe, rebound seismicity, although still occurring, is much less than in the early Holocene because the isostatic readjustment is in an asymptotic decline. Triggers, such as cyclic loading by storm waves are also climatically controlled. Continuing earthquake activity associated with glacioisostatic readjustment al ong the Scotia margin suggests that there is on ongoing hazard here.

\subsection{Climate and sea level change, and the preservation potential of tsunamis sediments from SMF $\mathbf{s}$.}

The identification of so few tsunamis sourced from SM F is enigmatic. The magnitude of tsunamis from SM Fs is determined mainly by the type of failure (cohesive slump or fragmental landslide), SM F volume and the water depth (Tappin et al., 2008). Slumps per unit volume are most hazardous, although fragmental failures are more voluminous and, therefore, potentially as hazardous. However, any SM F of sufficient volume and in appropriate water depths has the potential to create a hazardous tsunami. That SM F sourced tsunamis have only been identified along continental and convergent margins 
and fjords is thus considered unlikely to be representative, and it is the evidence base that is inadequate to fully identify the hazard.

Limitations on the identification of tsunamis may be due to the limited anecdotal evidence from survivors (for historical events) or, for prehistorically tsunamis, an absence of tsunami sediment laid down on inundation. Of recent SM F generated tsunami, such as those of the Grand Banks, 1929 and PNG, 1998 there have been positive identifications of associated sediments. The prehistorical event from Storegga, laid down sediment that extends as far afield as the Faeroe Islands. It is almost certain that tsunamis were also sourced from A ndøya, Trænadjupet, Finneidfjord; the absence of associated sediments from these events is puzzling. The assumption is that any resulting deposits have not been preserved.

Modelling of the Cape Fear and Currituck SM Fs indicates that at present sea levels failure would create a hazardous tsunami. As the failures took place either during the late glacial or early interglacial, at the time of failure the tsunami would have made a major impact. The lack of evidence of tsunami from onshore (or in fact offshore cored sediments) can be explained by the poor preservation potential of tsunami deposits that may lie on the seabed. Reworking during post-glacial periods may have eroded them however. The absence of deposits onland may be due to the width of the US continental shelf. Given that SM F took place at sea levels $\sim 100 \mathrm{~m}$ lower than today it is unlikely that the tsunami carried completely across the width of the US continental shelf that in places is up to $200 \mathrm{~km}$. B oth the large-scale SM F off the A mazon and the smaller SM Fs off west A frica have the potential to generate tsunamis, the absence of evidence in these areas, may be due to the timing (failure during lowered sea levels) or the lack of investigation in onshore areas to determine whether sediments resulting from these events are present.

The low preservation potential of sediments laid by tsunamis suggests that the prehistorical record maybe unrepresentative. Tsunamis during low stands may not have left a deposit on present day land, but on the present-day flooded continental shelf where, identification is compromised by difficulties in identification in cores or absence due to sediment reworking during postglacial transgression. For example, this may explain the lack of evidence of tsunamis sourced from the SM Fs off of the eastern US (e.g. Carrituck and Cape Fear), despite their large volume and modelling that would suggest otherwise.

The absence of evidence for tsunamis on active river deltas is intriguing. The similarity between sedimentation mechanisms on river deltas and other landslide territories, such as continental margins and fjords, in both sediment preconditioning and triggering suggests that SMFs of sufficient volume and at appropriate depths would generate tsunami. The water depths (less than $1000 \mathrm{~m}$ ) of known failures in the Gulf are certainly shallow enough to generate tsunamis, if the SM Fs are of sufficient volume. On the Gulf Coast the most catastrophic seabed failure was in 1969, when Hurricane Camille struck. Three offshore drilling platforms collapsed as a result of seabed sediment failure that resulted in a change of seabed relief of up to $12 \mathrm{~m}$ (e.g. 
Bea et al., 1983). Thus the SMFs are either too small or the tsunami wave was indistinguishable from the storm surge. In the instance of $\mathrm{K}$ atrina in 2005 the surge was between 6 and $9 \mathrm{~m}$, probably of a sufficient magnitude to mask a tsunami.

\section{Conclusions}

The hazard and risk from SM F sourced tsunami has advanced significantly over the past decade. SMFs are generally acknowledged to source hazardous tsunamis, however, the database of well-studied events is still limited. There is a recognisable and strong climate control on SM F that impacts on their potential to source hazardous tsunamis. There are strong climate controls on the type of SM F sediment and its' rate of delivery. Climate can precondition sediment instability by introducing 'weak layers' as well as through fluid and gas overpressuring. Climate influences triggering through earthquake shock and wave loading. There is an obvious latitudinal variation in SM F architecture that suggests tsunami hazard to be greater in northern regions. During glacial periods, rates of sediment delivery are higher and sediment volumes are larger, thus forming larger SM Fs that are more prone to failure. Along convergent margins, where earthquakes are more frequent, there is a climate influence in high latitudes.

A ny SMF of sufficient volume in an appropriate water depth has the potential to generate a hazardous tsunami. A t first sight, as in the North A tlantic, the presence of numerous SMFs suggests a present-day high risk. Consideration of the climate controls on SMF, however, indicates that these SMF took place under different environmental conditions. Their number, therefore, may not reflect present day hazard. The evidence base for the conclusions here, however, is still small. There are still too few case studies of actual events. M ore dates of Iandslide failure are required to test hypotheses on climate control of mass failure processes. The absence of tsunamis off deltas is enigmatic. The general absence of evidence for tsunamis where there are numerous SM Fs may be misleading and may be attributed to limited defining evidence from anecdote, absence of preserved deposits or misinterpretation of tsunami source.

Notwithstanding, consideration of climate controls on SM F contributes significantly in improving our understanding of SM F mechanisms, allowing an improved assessment of their sources as hazardous tsunami under present climatic conditions. In the future, as climate warms, this improved understanding will underpin prediction of tsunamisourced SM F, particularly in regions where climate change will be most rapid, such as in the Polar Regions.

Acknowledgments This paper is published with the permission of the Director of the British Geological Survey, Natural Environment Research Council, UK. M any thanks to Dr Simon Day for a comprehensive and analytical review.

\section{References}

Antobreh, A A, and Krastel, S. 2006. Morphology, seismic characteristics and development 
of Cap Timiris Canyon, offshore Mauritania: A newly discovered canyon preserved-off a major arid climatic region. M arine and Petroleum G eology, $\mathrm{V}$ ol. 23, 37-59.

Ashabranner, L B, Tripsanas, E K, and Shipp, R C. 2009. Multi-direction Flow in a MassTransport Deposit, Santos B asin, Offshore Brazil. 247-255 in Submarine M ass M ovements and Their Consequences. M OSHer, D C, Shipp, R.C., M OSCARDILlI, L., ChAYTOR, J.D., BAXTer, C.D.P., LEE, H.J. AND URGELES, R. (editor). (Springer.) BEA, R G, WRIGHT, S G, SICAR, P, and Niedoroda, A W. 1983. Wave-induced slides in South Pass Block 70, Mississippi delta. J ournal of Geotechnical Enginering, V ol. 109, 619-644.

BETTS, R, and M CGUIRE, W J. 2010. Warmer-world drivers of geological and geomorphological hazards. Proceedings of the Royal Society of London, $V$ ol. this volume.

Billi, A, Funiciello, R, Minelli, L, Faccenna, C, Neri, G, Orecchio, B, and Presti, D. 2008. On the cause of the $1908 \mathrm{M}$ essina tsunami, southern Italy. Geophysical Research Letters, Vol. 35.

Biscontin, G, Pestana, J M, and NAdim, F. 2004. Seismic triggering of submarine slides in soft cohesive soil deposits. Marine $\mathrm{G}$ eology, $\mathrm{V}$ ol. 203, 341-354.

Bohannon, R G, and Gardner, J V. 2004. Submarine landslides of San Pedro Sea Valley, southwest L ong B each, California. M arine G eology, V ol. 203, 261-268.

BONDEVIK, S, MANGERUD, J, DAWSON, S, DAWSON, A, and LOHNE, Ø. 2005. Evidence for three North Sea tsunamis at the Shetland Islands between 8000 and 1500 years ago. Quaternary Science Reviews, V ol. 24, 1757-1775.

Bryn, P, Berg, K, Forsberg, C F, Solheim, A, and Lien, R. 2005. Explaining the Storegga Slide. Marine and Petroleum G eology, Vol. 22, 11-19.

BUGGE, T. 1983. Submarine slides on the Norwegian continental margin, with special emphasis on the Storegga area. IKU Report, V ol. 110, 1-152.

CASHman, K V, and Popenoe, P. 1985. Slumping and shallow faulting related to the presence of salt on the continental slope and rise off North Carolina. M arine and Petroleum Geology, V ol. 2, 260-271.

ChAytor, J D, TWICHELL, D C, TEN BRINK, U S, BuCZKOWSKI, B J, and ANDREWS, B D (editors). 2007. Revisiting submarine mass movements along the U.S. Atlantic continental margin: implications for tsunami hazard. Submarine Mass Movements and their Consequences. (Springer.)

COULTER, H W, and Migliaccio, R R. 1966. Effects of the earthquake of March 27, 1964 at V aldez, A laska 542-C. US G eol. Survey Prof., Paper 542-E.

Dan, G, SULtan, N, and SAvoye, B. 2007. The 1979 Nice harbour catastrophe revisited: Trigger mechanism inferred from geotechnical measurements and numerical modelling. Marine Geology, V ol. 245, 40-64.

DINGLE, R V. 1977. A natomy of a large submarine slump on sheared continentgal margin (southeast A frica). J ounal of the G eological Society of London, V ol. 134, 293-310.

DOBSON, M R, O'LEARY, D, and VEART, M. 1998. Sediment delivery to the Gulf of Alaska: source mechanisms along a glaciated transform margin. Geological Society, London, Special Publications, Vol. 129, 43-66.

DugAN, B, and StigALL, J. 2009. Origin of Overpressure and Slope Failure in the Ursa Region, Northern Gulf of Mexico. 167-178 in Submarine Mass Movements and Their Consequences. M osher, D C, Shipp, R.C., M oscardilli, L., Chaytor, J.D., Baxter, C.D.P., Lee, H.J. And URGELES, R. ET AL. (editor). (Springer.)

EMBLEY, R W, and JACOBI, R D. 1986. M ass wasting in the western North A tlantic. 479-490 in The Western North Atlantic Region: Geology of North America. V OGT, P R, TUCHOLKE, B.E. (editor). (B oulder, CO: M emoir of the Geological Society of A merica.)

Fisher, M A, Normark, W R, Greene, H G, Lee, H J, and Sliter, R W. 2005. Geology and tsunamigenic potential of submarine landslides in Santa Barbara Channel, Southern California. M arine G eology, $\mathrm{V}$ ol. 224, 1-22.

Fritz, H M, Kongko, W, Moore, A, McAdoo, B, Goff, J, Harbitz, C, Uslu, B, Kalligeris, N, 
Suteja, D, Kalsum, K, Titov, V, Gusman, A, Latief, H, Santoso, E, Sujoko, S, Djulkarnaen, D, Sunendar, H, and SYNOLAKIS, C. 2007. Extreme runup from the 17 July 2006 J ava tsunami. Geophys. Res. Lett., V ol. 34.

Fryer, G J, Watts, P, and Pratson, L F. 2004. Source of the great tsunami of 1 A pril 1946: a landslide in the upper Aleutian forearc. M arine G eology, V ol. 203, 201-218.

Gee, M J R, M asson, D G, W atTs, A B, and A LLEN, P A. 1999. The Saharan debris flow: an insight into the mechanics of long runout submarine debris flows. Sedimentology, $\mathrm{V}$ ol. 46, 317-335.

GEIST, E L, LYNETT, P J, and CHAYTOR, J D. 2009. Hydrodynamic modeling of tsunamis from the Currituck landslide. Marine G eology, Vol. 264, 41-52.

Goldfinger, C, KULM, L D, MCNeILL, L C, and WATTS, P. 2000. Super-scale failure of the southern Oregon Cascadia margin. 1189-1226 in Landslides and Tsunamis. KEATING, B, WaYthomas, C, and DAWSON, A (editors). 157. (Pure and A pplied Geophysics.)

Greene, H G, Murai, L Y, Watts, P, Maher, N A, Fisher, M A, Paull, C E, and Eichhubl, P. 2005. Submarine landslides in the Santa Barbara Channel as potential tsunami sources. Natural Hazards and Earth System Sciences, V ol. 6, 63-88.

GrozIC, J L H. 2009. Interplay Between Gas Hydrates and Submarine Slope Failure. 11-30 in Submarine Mass M ovements and Their Consequences. M OSHER, D C, SHIPP, R.C., M OSCARDILLI, L., Chaytor, J.D., Baxter, C.D.P., Lee, H.J. ANd URGeles, R. (editor). (Springer Science + Business M edia.)

Ham Pton, M A, LeE, H J, and LocAt, J. 1996. Submarine Landslides. Reviews of Geophysics, Vol. 34, 33-59.

Hampton, M A, LemKe, R W, and Coulter, H W. 1993. Submarine landslides that had a significant impact on man and his activities: Seward and V aldez, Alaska. 123-142 in Submarine Landslides: Selected Studies in the US EEZ. Schwab, W C, Lee, H J, and TwiChelL, D C (editors). 2002. (USGS Bulletin.)

HeEZEN, B C, ERICSSON, D B, and EWING, M. 1954. Further evidence of a turbidity current following the 1929 Grand Banks earthquake. D eep Sea Research, V ol. 1, 193- 202.

Henrich, R, Hanebuth, T J J, Cherubini, Y, Kraste, S, Pierau, R, and Zühlsdorff, C. 2009. Climate-Induced Turbidity Current A ctivity in NW -A frican Canyon Systems. Submarine Mass Movements and Their Consequences. M OSHER, D C, SHIPP, R.C., M OSCARDILLI, L., ChAYTOR, J.D., BAXTER, C.D.P., LEE, H.J. AND U RGELES, R. (editor). (Springer.)

Henrich, R, Hanebuth, T J J, Krastel, S, Neubert, N, and Wynn, R B. 2008. A rchitecture and sediment dynamics of the M auritania Slide Complex. M arine and Petroleum Geology, $\mathrm{V}$ ol. 25, 17-33.

Hjelstuen, B O, SejRup, H P, Haflidason, H, NyGa ${ }^{\circ}$ Rd, A, Ceramicola, S, and Bryn, P. 2005. Late Cenozoic glacial history and evolution of the Storegga Slide area and adjacent slide flanks regions, Norwegian continental margin. Marine and Petroleum Geology, 57-69.

HORNBACH, M J, LAVIER, L L, and RUPPEL, C D. 2007. Triggering mechanism and tsunamogenic potential of the Cape Fear Slide complex, U.S. A tlantic margin. Geochem. Geophys. Geosyst., V ol. 8. Q12008. (doi:10.1029/2007GC001722)

HÜHNERBACH, V, M ASSON, D G, and PARTNERS, C P. 2004. Landslides in the north A tlantic and its adjacent seas: an analysis of their morphology, setting and behaviour. Marine Geology, $\mathrm{V}$ ol. 213, 343-362.

Imamura, F, Gica, E, TAKahashi, T, and Shuto, N. 1995. Numerical simulation of the 1992 Flores tsunami: Interpretation of tsunami phenomena in northeastern Flores Island and damage at B abi Island. Pure appl. geophys., V ol. 144, 555-568.

JenNer, K A, PIPER, D J W, CAM PBELL, D C, and M OSHER, D C. 2007. Lithofacies and origin of late Quaternary mass transport deposits in submarine canyons, central Scotian Slope, Canada. Sedimentology, V ol. 54, 19-38.

JIANG, L, and LEBLOND, P H. 1994. Three dimensional modelling of tsunami generation due to submarine mudslide. J. Phys. Ocean, V ol. 24, 559-573.

JOHNSON, R W. 1987. Large-scale volcanic cone collapse: the 1888 slope failure of Ritter V olcano, and other examples from Papua N ew Guinea. Bulletin of Volcanology, V ol. 49, 669-679. 
Kawamura, K, Kanamatsu, T, Kinoshita, M, Saito, S, Shibata, T, Fujino, K, Misawa, A, and BURMEISTER, K C. 2009. Redistribution of Sediments by Submarine Landslides on the Eastern Nankai A ccretionary Prism. Submarine M ass M ovements and Their Consequences. M OSHER, D C, Shipp, R.C., Moscardilli, L., Chaytor, J.D., Baxter, C.D.P., Lee, H.J. and URgeles, R. (editor). 28. (Springer.)

Kvalstad, T J, Andresen, L, Forsberg, C F, Berg, K, Bryn, P, and Wangen, M. 2005. The Storegga Slide: evaluation of triggering sources and slide mechanics. Marine and $P$ etroleum Geology, Vol. 22, 245-256.

Laberg, J S, V OrRen, T O, Dowdeswell, J A, Keny On, N H, and TAYlor, J. 2000. The Andøya Slide and the Andøya Canyon, north-eastern Norwegian-Greenland Sea. M arine Geology, Vol. $162,259-275$.

Laberg, J S, V ORRen, T O, M Ienert, J, Haflidason, H, BRy , P, and Lien, R. 2003. Preconditions leading to the Holocene Trænadjupet slide offshore Norway. 247-254 in Submarine Mass Movements and their Consequences. LOCAT, J, and MIENERT, J (editors). (K luwer A cademic Publishers, The N etherlands.)

lastras, G, Canals, M, Urgeles, R, de Batist, M, Calafat, A M, and Casamor, J L. 2004. Characterisation of the recent BIG'95 debris flow deposit on the Ebro margin, Western M editerranean Sea, after a variety of seismic reflection data. M arine Geology, V ol. 213, 235255.

LEB LOND, P H, and J ONES, A. 1995. Underwater landslides ineffective at tsunami generation. Sci. Tsunami Hazards, V ol. 13, 25-26.

LEE, H J. 1989. Undersea landslides: extent and significance in the Pacific Ocean. 367-380, in Landslides, extent and economic significance. BRABB,E E, and HARROD, B L (editors). (W ashington, D.C.: Proc. of the 28th Inter. Geol. Cong.: symposium on landslides.)

$\mathrm{LEE}, \mathrm{H}$ J . 2009. Timing of occurrence of large submarine landslides on the A tlantic O cean margin. Marine G eology, V ol. 264, 53-64.

LEE, H J, KAYEN, R E, GARDNER, J V, and LOCAT, J. 2003. Characteristics of several tsunamigenics submarine landslides. 357-366 in Submarine M ass Movements and their Consequences. LOCAT, J, and M IENERT, J (editors). ( K luwer, The Netherlands.)

LEMKE, R W. 1967. Effects of the earthquake of 27 M arch 1964, at Seward, Alaska. US Geol. Survey Prof., Paper 542-E.

Locat, J, Lee, H, ten Brink, U S, Twichell, D, Geist, E, and Sansoucy, M. 2009. Geomorphology, stability and mobility of the Currituck slide. Marine G eology, V ol. 264, 28-40.

LOCAT, J, LOCAT, P, LEE, H J, and IMRAN, J. 2004. Numerical analysis of the mobility of the Palos $V$ erdes debris avalanche, California, and its implication for the generation of tsunamis. Marine Geology, Vol. 20, 269-280.

López-V ENEGAS, A M, BRINK, U S T, and GeIST, E L. 2008. Submarine landslide as the source for the October 11, $1918 \mathrm{M}$ ona Passage tsunami: Observations and modeling. M arine G eology, $\mathrm{V}$ ol. 254, 35-46.

Maslin, M, Betts, R, Day, S, Dunkley Jones, T, OWen, M, and Ridgwell, A. 2010. Gas Hydrates: an essential component in understanding past and future climate change hazards. Proceeding of the Royal Society of $L$ ondon, $V$ ol. this volume.

MASLIN, M, M IKKELSEN, N, VILELA, C, and HAQ, B. 1998. Sea-level -and gas-hydrate-controlled catastrophic sediment failures of the A mazon $\mathrm{F}$ an. G eology, $\mathrm{V}$ ol. 26, 1107-1110.

MASSON, D G, WYNn, R B, and TALLING, P J. 2009. Large Landslides on Passive Continental $M$ argins: Processes, Hypotheses and Outstanding Questions. Submarine Mass Movements and Their Consequences. M OSher, D C, Shipp, R.C., M OsCardilli, L., Chaytor, J.D., BaXter, C.D.P., LEE, H.J. AND URGELES, R. (editor). (Springer Science.)

MCAdoo, B, Pratson, G, and ORANGe, L F. 2000. Submarine Landslide Geomorphology, U.S. Continental Slope. Marine G eology, V ol. 169, 103-136.

MCADOO, B G, CAPONE, M K, and MINDER, J. 2004. Seafloor geomorphology of convergent margins: implications for Cascadia seismic hazard. Tectonics, $\mathrm{V}$ ol. 23.

M OORE, J G, NORMARK, W R, and Holcomb, R T. 1994. Giant Hawaiian Underwater Landslides. 
Science, Vol. 264, 46-47.

M OSHER, D C, and PIPER, D J W . 2007. A nalysis of multibeam seafloor imagery of the Laurentian Fan and the 1929 Grand Banks landslide area. 77-88 in Submarine Mass M ovements and their Consequences. LYKOUSIS, V, SAKELLARIOU, D, and LOCAT, J (editors). (Springer.)

Normark, W R, MCGann, M, and Sliter, R. 2004. Age of Palos Verdes submarine debris avalanche, southern California. M arine G eology, V ol. 203, 247-259.

PeLtier, W R. 2002. Global glacial isostatic adjustment: Palaeogeodetic and space-geodetic tests of the ICE-4G (V M 2) model. J ournal of Q uaternary Science, V ol. 17, 491-510.

PIPER, D J W, and ASKU, A E. 1987. The source and origin of the 1929 Grand Banks turbidity current inferred from sediment budgets. G eo M arine L etters, V ol. 7, 177-182.

PIPER, D J W, and M CCALL, C. 2003. A synthesis of the distribution of submarine mass movements on the eastern Canadian Margin. 291-298 in Submarine mass movements and their consequences. LOCAT, J, and M IENERT, J (editors). (K luwer A cademic Publishers.)

Piper, D J W, Pirmez., C, M Anley, P L, Long, D, R. D. Flood, Normark, W R, and Showers, W. 1997. M ass transport deposits of the Amazon Fan. 109-146 in Proceedings of the Ocean D rilling Program, Scientific results. FloOd, R D, PIPER, D J W, KLAUS, A, and Peterson, L C (editors). 155. (College Station, Texas (O cean D rilling Program).)

PLAfKer, G, KaChAdOORIAN, R, ECKEL, E B, and MAYO, L R. 1969. Effects of the earthquake of $M$ arch 27, 1964 on various communities, US Geol. Survey Prof., Paper 542-G.

Prior, D B, Bornhold, B D, Coleman, J M, and Bryant, W R. 1982a. Morphology of a submarine slide, Kitimat A rm, B ritish Columbia. G eology, V ol. 10, 588-592.

PRIOR, D B, BORNHOLD, B D, and JOHNS, M W. 1986. A ctive sand transport along a fjord-bottom channel, Bute Inlet, B ritish Columbia. Geology, V ol. 14, 581-584.

PrIOR, D B, and COLEMAN, J M. 1982. Active slides and flows on underconsolidated marine sediments on the slopes of the Mississippi delta. 21-49 in Marine slides and other mass movements. SAXOV, S, and NieuWENHUIS, J K (editors). (Plenum, New Y ork.)

PrIOR, D B, COLEMAN, J M, and BORNHOLD, B D. 1982b. Results of a known sea-floor instability event. Geomarine. Letters, V ol. 117-122, 2.

Prior, D B, Doyle, E H, and Neurauter, T. 1986. The Currituck Slide, mid-A tlantic continental slope -- Revisited. Marine Geology, V ol. 73, 25-45.

Rahiman, T I H, Pettinga, J R, and Watts, P. 2007. The source mechanism and numerical modelling of the 1953 Suva tsunami, Fiji. Marine G eology, V ol. 237, 55-70.

Rajendran, C P, Ramanamurthy, M V, Reddy, N T, and Rajendran, K. 2008. Hazard implications of the late arrival of the $1945 \mathrm{M}$ akran tsunami. Current Science, V ol. 95, 17391743.

SATAKE, K. 2007. Volcanic origin of the 1741 Oshima-O shima tsunami in the Japan Sea. Earth Planets Space, V ol. 59, 381-390.

SatAke, K, and Kato, Y. 2001. The 1741 Oshima-Oshima Eruption: Extent and Volume of Submarine Debris A valanche. G eophysical Research Letters, V ol. 28, 427-430.

SCHWAB, W C, and LEE, H J. 1988. Causes of two slope-failure types in continental-shelf sediment, northeastern Gulf of Alaska. J ournal of Sedimentary Research, $\mathrm{V}$ ol. 58, 1-11.

Siebert, L, Glicken, H, and UI, T. 1987. Volcanic hazards from Bezymianny- and Bandai-type eruptions. Bulletin of Volcanology, $\mathrm{V}$ ol. 49, 435-459.

Solheim, A, Bry N, P, SejRup, H P, M ienert, J, and Berg, K. 2005. Ormen Lange- an integrated study for the safe development of a deep-water gas field within the Storegga Slide Complex, NE A tlantic continental margin; executive summary. M arine and Petroleum G eology, $\mathrm{V}$ ol. 22, 1-9.

SOWERS, T. 2006. Late Quaternary A tmospheric CH 4 I sotope Record Suggests M arine Clathrates A re Stable. Science, $\mathrm{V}$ ol. 311, 838-840.

SYVITSKI, J P M, BURReLL, D C, and SKEI, J M. 1986. Fjords: Processes and Products. (Springer, New Y ork.)

TANiOKA, Y, and Seno, T. 2001. Sediment Effect on Tsunami Generation of the 1896 Sanriku Tsunami Earthquake. Geophysical Research Letters, V ol. 28, 3389-3392.

TAPPIN, D R. 2009. M ass Transport Events and Their Tsunami Hazard. 667-684 in Submarine Mass 
Movements and Their Consequences. M OSHER, D C, SHIPP, R.C., M OSCARDILLI, L., ChAYTOR, J.D., BAXTER, C.D.P., LEE, H.J . AND U RGELES, R. (editor). (Springer Science + Business M edia.)

Tappin, D R, M atsum Oto, T, Watts, P, SATAKe, K., M CM URTRY, G M, Matsuyama, M, Lafoy, Y, Tsuj, Y, Kanamatsu, T, Lus, W, Iwabuchi, Y, Yeh, H, Matsumotu, Y, Nakamura, M, M AHOI, M, HILL, P, CROOK, K, ANTON, L, and WALSH, J P. 1999. Sediment slump likely caused 1998 Papua N ew Guinea Tsunami. EOS, Transactions of the American Geophysical U nion, V ol. $80,329,334,340$.

TAPPIN, D R, M CNEIL, L, HENSTOCK, T, and M OSHER, D. 2007. M ass wasting processes - offshore Sumatra. 327-336 in Submarine Mass Movements and Their Consequences. LYKoUSIS, V, SAKELLARIOUS, D, and LOCAT, J (editors). (Springer.)

TAPpin, D R, WATtS, P, and GRILLI, S T. 2008. The Papua N ew Guinea tsunami of 17 July 1998: anatomy of a catastrophic event. Nat. Hazards Earth Syst. Sci., V ol. 8, 243-266.

Tappin, D R, Watts, P, M cM URTRY, G M, LAFOY, Y, and Matsumoto, T. 2001. The Sissano Papua N ew Guinea tsunami of July 1998 - offshore evidence on the source mechanism. Marine G eology, V ol. 175, 1-23.

TWICHELL, D C, ChAYTOR, J D, TEN BRINK, U S, and BUCZKOWSKI, B. 2009. M orphology of late Q uaternary submarine landslides along the U.S. A tlantic continental margin. Marine Geology, Vol. 264, 4-15.

Urgeles, R, Canals, M, Baraza, J, B.Alonso, and Masson, D. 1997. The most recent megal andslides of the Canary Islands: el Golfo debris avalanche and Canary debris flow, west el Hierro Island. J ournal of G eophysical Research, V ol. 102(B 9), 20,305-320,323.

WARD, S N, and DAY, S. 2003. Ritter Island Volcano- Lateral collapse and the tsunami of 1888. G eophysical J ournal International, V ol. 154, 891-902.

Weaver, P P E, WYnn, R B, KenYON, N H, and Evans, J. 2000. Continental margin sedimentation, with special reference to the north-east A tlantic margin. Sedimentology, V ol. 47 (Suppl. 1), 239225.

Wynn, R B, WeAVer, P P E, MASSON, D G, and Stow, D A V. 2002. Turbidite depositional architecture across three inter-connected deep-water basins on the Northwest A frican M argin. Sedimentology, V ol. 49, 669-695. 